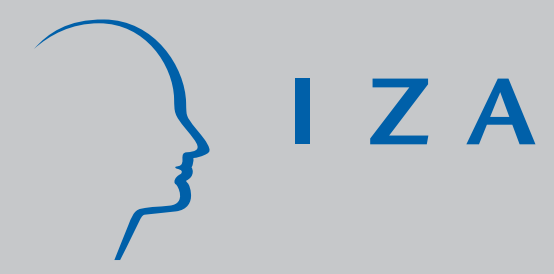

IZA DP No. 3947

\title{
On Mandatory Activation of Welfare Recipients
}

Matz Dahl berg

KajsaJ ohansson

Eva Mörk

J anuary 2009 


\title{
On Mandatory Activation of Welfare Recipients
}

\author{
Matz Dahlberg \\ Uppsala University, \\ IFAU and CESifo \\ Kajsa Johansson \\ Uppsala University \\ Eva Mörk \\ IFAU, Uppsala University \\ and IZA
Discussion Paper No. 3947
January 2009 \\ IZA \\ P.O. Box 7240 \\ 53072 Bonn \\ Germany \\ Phone: +49-228-3894-0 \\ Fax: +49-228-3894-180 \\ E-mail: iza@iza.org
}

Any opinions expressed here are those of the author(s) and not those of IZA. Research published in this series may include views on policy, but the institute itself takes no institutional policy positions.

The Institute for the Study of Labor (IZA) in Bonn is a local and virtual international research center and a place of communication between science, politics and business. IZA is an independent nonprofit organization supported by Deutsche Post World Net. The center is associated with the University of Bonn and offers a stimulating research environment through its international network, workshops and conferences, data service, project support, research visits and doctoral program. IZA engages in (i) original and internationally competitive research in all fields of labor economics, (ii) development of policy concepts, and (iii) dissemination of research results and concepts to the interested public.

IZA Discussion Papers often represent preliminary work and are circulated to encourage discussion. Citation of such a paper should account for its provisional character. A revised version may be available directly from the author. 


\section{ABSTRACT \\ On Mandatory Activation of Welfare Recipients*}

This paper investigates whether mandatory activation programs for welfare recipients have effects on welfare participation, employment and disposable income. In contrast to earlier studies, we are able to capture both entry and exit effects. The empirical analysis makes use of a Swedish welfare reform in which the city districts in Stockholm gradually implemented mandatory activation programs for individuals on welfare. Overall, we find that mandatory activation of welfare recipients reduces overall welfare participation and increases employment. We also find that mandatory activation programs appear to work best for young people and for people born in non-Western countries.

JEL Classification: $\quad$ I38, H31

Keywords: welfare reform, mandatory activation programs, welfare participation, employment, difference-in-differences

Corresponding author:

Eva Mörk

Uppsala University

PO Box 513

SE-751 20 Uppsala

Sweden

E-mail: eva.mork@ifau.uu.se

\footnotetext{
Constructive and useful comments from Olof Åslund, Pedro Carneiro, Per-Anders Edin, Peter Fredriksson, Nils Gottfries, Erik Grönqvist, Per Johansson, Katarina Thorén and seminar participants at Uppsala, Helsinki, Växjö, the 2008 SOLE conference in New York, the 2007 COST-meeting on "The Evaluation of European Labour Market Programmes" in The Hague, The RTN-meeting in Uppsala 2008 , the $2^{\text {nd }}$ joint IZA/IFAU Conference on Labor Market Policy, the CESifo conference "Reform of the Welfare State: A New European Model" in Munich 2008, and SUDSWEC are gratefully acknowledged. The usual disclaimer applies. A research grant from the Swedish Council for Working Life and Social Research (FAS) is gratefully acknowledged.
} 


\section{Introduction}

Mandatory activation of welfare recipients is a commonly used practice both in the U.S. and in Europe. For example, in the years preceding the major U.S. welfare reform in 1996, a number of states, through state waivers, implemented different types of mandatory welfare-to-work programs (see, e.g., Hamilton, 2002). Work requirements were also one of the major components imposed by the PRWORA legislation in $1996 .{ }^{1}$ The idea behind mandatory activation is that conditioning welfare on requirements to work or to engage in work-related activities, such as education, training or job search, will work as a screening device separating the truly needy from those who are not, and at the same time, the activation itself will increase the productivity of those who are unable to get a job. ${ }^{2}$ Besley and Coate (1992) formalize the mechanism behind activation requirements and show that activation may have both short- and long-run effects on welfare caseloads. ${ }^{3}$

From several randomized experiments, we have obtained a rather good picture of the effects of mandatory activation on program participants (i.e., on exit effects; see, e.g., Hamilton, 2002, who focuses on the 11 projects that were implemented under the National Evaluation of Welfare-to-Work Strategies (NEWWS) Program). ${ }^{4}$ What is missing, however, are studies that also take possible entry effects into account. This is a serious shortcoming for two reasons. First, as is clear from the theoretical model put forth by Besley and Coate (1992), it is the threat of activation rather than activation per

\footnotetext{
${ }^{1}$ For good overviews of this reform, see Blank (2002), Grogger and Karoly (2005), and Moffitt (2007).

2 The idea has a long tradition in societal program design dating back to, e.g., the English Poor Laws, according to which "no able-bodied person was to receive money or other help from the Poor Law authorities except in a workhouse".

${ }^{3}$ Also, Grogger and Karoly (2005) present an economic model describing how mandatory activation reduces welfare use as well as welfare payments.

${ }^{4}$ Among the programs that involved mandatory activation, there existed two types of programs, those with an employment-focused approach and those with an education-focused approach. In addition, there were also some programs that applied mixes of the two approaches. The evidence from this research indicates that the programs increased employment and decreased welfare benefits among participants, but had no net effect on the participants' economic well-being. Also, programs that emphasized short-term job search assistance and encouraged participants to find jobs quickly already had positive effects on employment after year one, whereas programs that emphasized longer-term skill-building activities took some time to have effects. After five years, however, the second type of program had caught up with the job-first programs (see Hamilton, 2002). Most successful were the programs that combined the two approaches. See also Bloom and Michalopoulus (2001), who present an overview of the results from 29 welfare reform initiatives in the U.S. and Canada.
} 
se that matters. Second, among others, Grogger et al. (2003) and Moffitt (2007) argue that much of the decline in welfare use and caseloads following the U.S. welfare reform in 1996 was due to decreased entry rather than to increased exit. ${ }^{5}$

In this paper, we will use quasi-experimental data from a Swedish welfare reform in order to empirically investigate to what extent conditioning welfare on participation in work-related activities reduces the number of people on welfare. As opposed to earlier studies, we are able to observe both entry and exit effects, although we are not able to distinguish between the two. Through the reform, mandatory activation programs were implemented gradually in the city districts in Stockholm over the period of 1998 to 2004. We will use this gradual implementation in a difference-in-differences setup. Using data from city districts within a single local labor market has large advantages, since it makes it possible to control for macroeconomic shocks, something that is difficult when using, e.g., data on U.S. states. Also, the reform was "clean” in the sense that the activation programs for welfare recipients were implemented in isolation, hence not accompanied by, e.g., financial incentives, like the EITC, or time limits. Finally, having access to very rich individual-level register data (on all individuals living in Stockholm over the period 1993-2003), we can also investigate whether the effects are heterogeneous with respect to, e.g., age and country of birth, as well as investigating the effects on a number of important outcomes, such as employment and disposable income.

Overall, we find that the activation programs decrease welfare participation and increase employment. However, the effects are different across groups; in particular, mandatory activation has especially strong positive effects for immigrants and young people. We do not, however, find any significant effects on disposable income.

The remainder of the paper is organized as follows: the next section describes the Swedish welfare system and the activation programs in Stockholm. In section 3, the data used are described, and in section 4, we present the empirical strategy that is employed. The main results are presented in section 5, whereas section 6 investigates

\footnotetext{
${ }^{5}$ It can also be mentioned that in a related literature on unemployment insurance (UI), there exist two studies that both find that workfare, or the threat of workfare, decreases the length of time that participants remain on UI; see Benus and Johnson (1997) and Black et al. (2003).
} 
the dynamics of the effects. Section 7 examines whether there are heterogeneous effects, and section 8 summarizes the paper and concludes.

\section{Welfare in Sweden}

The Swedish social security system is often considered one of the most extensive and generous systems in Western welfare states. The responsibility for supplying welfare benefits (the Swedish term is "social assistance") rests with the local governments, even though The Social Services Act constitutes the framework for welfare benefits. It is constructed as a frame law, which means that the interpretation and enactment of the law is delegated to each municipality. Since 1982, the law ensures that all Swedish and foreign citizens living in Sweden have the right to obtain welfare benefits in the absence of other means of economic support. As opposed to the situation in many other countries (e.g., the U.S. and U.K.), receiving welfare is not dependent on having children. However, in order to be eligible for welfare benefits, all other means, including savings and valuable assets, must be exhausted. The benefit level should ensure a reasonable standard of living, but it is up to the municipalities to decide the exact level. However, until 1998, there existed recommendations from the National Board of Health and Welfare, and since 1998 these recommendations have been replaced by a minimum level.

In 2006, 392,500 individuals (or about 4.3 percent of the population) received welfare benefits (some of the recipients were newly arrived immigrants). About 30 percent of these received welfare more than 10 months during a year and are therefore defined as long-term recipients. Figure 1 describes the development of the number of welfare recipients as well as the costs for welfare benefits from the mid-1980s up to 2006. As can be seen from the figure, starting at the end of the 1990s, both the number of individuals receiving welfare and the costs for welfare benefits have dropped. However, the costs per recipient (not shown in the figure) have increased, indicating that the individuals who are still on welfare remain so for a longer time. In 1999, the Swedish government declared an ambition to cut costs for welfare benefits in half, but this objective has proven hard to accomplish; even though welfare costs have decreased 
over time, they have not decreased by 50 percent. Also, since 2003, the decrease seems to have ended.

Figure 1 Welfare households (100's) and costs (m. of SEK) for welfare benefits 19832007.

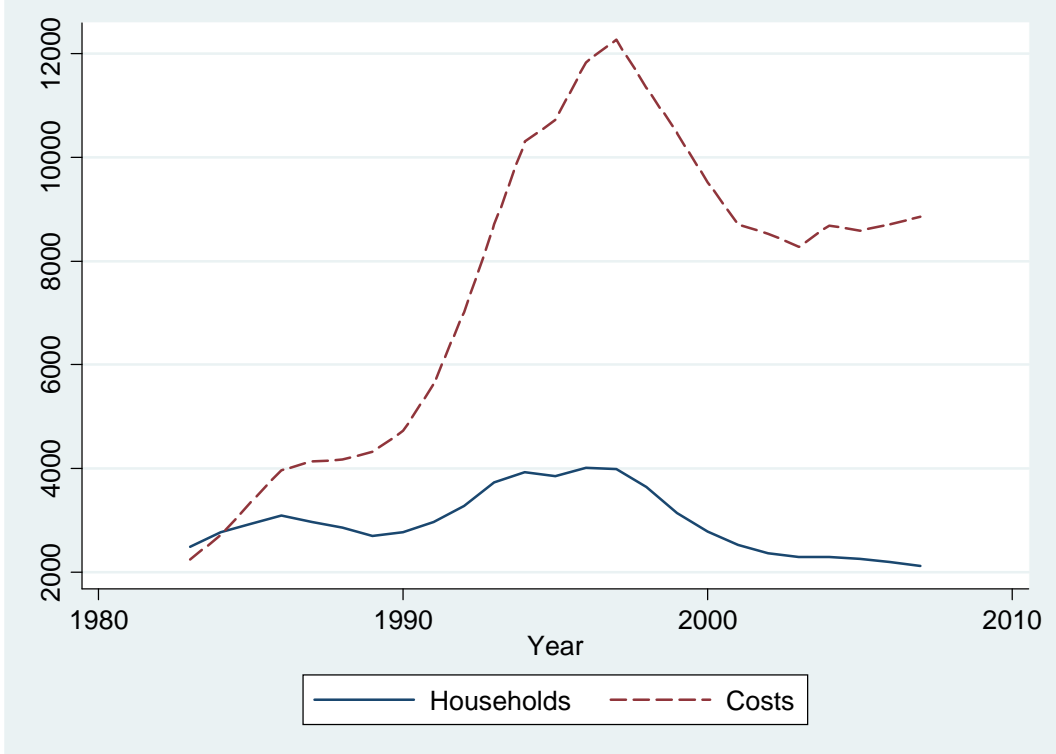

Source: Statistics Sweden.

Welfare recipients are not evenly spread across different groups in society. The probability of receiving welfare is largest among unemployed youths without eligibility for unemployment benefits, single mothers and individuals born outside Western countries.

During the 1980s, the right to welfare was not tied to any specific requirements on the recipient of welfare benefits other than having exhausted all other means of financing and being available for work. "Being available for work" was in the early 1980s defined by The National Board for Health and Welfare as searching for jobs and not turning down any "suitable offers". A "suitable offer" was perceived as a job matching the skills and qualifications of the individual and in line with collective agreements. However, as the recession of the 1990s led to difficulties in financing the social welfare system, the right to welfare became subject to stricter means-testing, and the requirement of being available for work was extended to also include participation 
in internships and labor market projects. ${ }^{6}$ At the same time, the generosity of welfare benefits was reduced in many municipalities.

The right to require participation in activation programs by welfare recipients was formally introduced by a change in the Social Services Act in $1998 .^{7}$ The new law made it possible for municipalities and city districts to demand participation in work-related activities, such as internships and supervised job searches, in return for welfare benefits.

In this paper, we will focus on the city districts in the city of Stockholm. The city of Stockholm is by far Sweden's largest municipality, with approximately 780,000 inhabitants in 2006. It makes up the central part of a much larger labor market area. Next, we will turn to a description of the programs in place in Stockholm.

\section{Empirical setting}

During the period studied (1993-2003), the municipality of Stockholm was divided into 18 city districts (see Map in Appendix A). ${ }^{8}$ The city districts are responsible for the majority of the municipality's services within their geographical areas. ${ }^{9}$ However, the municipality sets taxes ${ }^{10}$ and allocates funds between the city districts. In addition, it, through guidelines, defines overall goals. The political composition in the District Councils is equivalent to that of the Municipal Council, which is elected every fourth year. Hence, there are no elections at the city district level, and the political majority is the same all over Stockholm.

The earliest examples of activation programs in Stockholm are from 1998 and 1999, when Rinkeby and Skärholmen introduced programs intended to enroll all unemployed

\footnotetext{
${ }^{6}$ For a discussion of the welfare system during the 1990s, see Johansson (2000, 2001) and Bergmark (2000).

${ }^{7}$ Many of the changes prescribed by the 1998 law reflected trends that had been in practice earlier; Salonen and Ulmestig (2001) show that many municipalities seem to have applied rules similar to the new policy even before 1998. Also, the rule has been used in a wider sense, for example, to apply to groups other than youths.

${ }^{8}$ On January 1, 2007, the number of city districts decreased to 14.

${ }^{9}$ The districts' responsibilities include refugee reception services, recreational programs for children and youth, preschool, income support, budgetary counseling and debt restructuring, consumer advisory services, local business and labor market initiatives, local urban environment issues, maintenance of parks, services and care for the disabled, social services, care and treatment, family law, and elderly services.

${ }^{10}$ In Sweden, municipalities have the right to collect revenues from a local, proportional, income tax. They are also allowed to charge user fees for some of the services they provide.
} 
welfare recipients in job searching activities. ${ }^{11}$ They were followed by Kista and Farsta in 2001 and by many other city districts since then. In fact, since 2004 there have been mandatory activation programs in force in all city districts.

These programs have been known under the name "activation programs" and typically require a number of hours' attendance each week. According to the official descriptions, the aims of the programs are to facilitate job searches for the unemployed and to "coach" the participants to become self-supporting. However, in a case study by Thorén (2005), it is concluded that "municipal activation policy in its practical form will not necessarily improve client's prospects to find employment since its primary function rather is as a method to control clients' entitlement to social assistance”. The organization of the programs makes it possible for the welfare administration to monitor the willingness to work.

In order to determine when the different city districts launched mandatory activation, we have disseminated a questionnaire addressed to the heads of the welfare administration in each city district. ${ }^{12}$ The questionnaire was complemented with telephone interviews whenever it was difficult to categorize a program based on the information given in the questionnaire. Based on the information from the questionnaire and the interviews, we can determine in which year a mandatory program was launched in each city district. In order to be labeled as “a mandatory program”, it must be directed toward all unemployed individuals receiving social assistance and require attendance for some hours per week. The programs all use a common reporting system in which the participants' attendance is recorded daily. Most importantly, the register is open to social workers, which means that absence is immediately detected and will in many cases lead to reduced benefits. Some of the programs are extensions of previous

\footnotetext{
${ }^{11}$ It is noteworthy that, as opposed to in some other Swedish municipalities, there did not exist any large scale activation programs in any of the Stockholm city districts before 1998 when the Social Service Act was changed.

${ }^{12}$ The questionnaire is given in Appendix B.
} 
programs, but the ambitions of the current programs are much higher. ${ }^{13}$ Table 1 shows when the activation programs subject to this study were implemented. ${ }^{14}$

A valid question is of course whether we can trust the answers given by the welfare administrators. Do the programs really include all individuals receiving welfare, and are they as harsh as the administrator claims? Without conducting thorough implementation studies, we can of course never be 100 percent certain. ${ }^{15}$ However, as far as we know, there are no reasons for the administration not to tell the truth. Also, it is worth noting that if the programs are in fact not as compulsory and "tough" as stated by the heads of the welfare administration, we would get estimates that, if anything, are biased towards zero. Hence, the effect that we find in the paper should be seen as a lower bound of the effects of general activation programs.

Table 1 Starting years for activation programs in Stockholm city districts

\begin{tabular}{lc}
\hline District & Year \\
\hline Skärholmen & 1999 \\
Farsta & 2001 \\
Kista & 2001 \\
Älvsjö & 2002 \\
Hägersten & 2003 \\
Liljeholmen & 2003 \\
Spånga-Tensta & 2003 \\
Bromma & 2004 \\
Enskede-Årsta & 2004 \\
Hässelby-Vällingby & 2004 \\
Vantör & 2004 \\
\hline
\end{tabular}

\footnotetext{
${ }^{13}$ In the earlier years, job seeking activities were often limited to occasional contacts with an employment counselor, whose role mostly consisted of discussing the client's situation and possibly arranging labor market training. Cooperation between the social administration and consultants was scarce, and a common view is that the follow-up was insufficient.

${ }^{14}$ Since our data end in 2003, the programs started in 2004 are not used in the identification of the program effect. Also, in one district (Skarpnäck) it is impossible to establish when the "ambitious" program began, and Skarpnäck is therefore excluded. In addition, the most central city districts are excluded from the sample altogether as the share of recipients of welfare benefits is very low in this part of the city and their methods are difficult to categorize. Finally, Rinkeby is excluded from the analysis since it is an outlier in several respects, not the least in terms of welfare participation and share of inhabitants born outside Sweden. We have also estimated the model when excluding other city districts, one at the time, and it turns out that Rinkeby seems to be different. It is important to remember that excluding Rinkeby implies that we cannot draw inference from our results to city districts like Rinkeby.

${ }^{15}$ We would like to stress that the questionnaire has been complemented with several telephone conversations where we have tried to get more detailed information when needed. In addition, in the interviews we ask about programs that have actually been in place for a number of years, making it likely that it is the actual program, not just the ambitions of the program, that we capture.
} 
In order to provide a better understanding of the programs, we will describe the program in Skärholmen in more detail. The program in Skärholmen is one of the most documented programs (see Ekström, 2005 and Thorén, 2005 for a more detailed description), and it is to a large extent comparable to other, less documented programs in other parts of the city. ${ }^{16}$ For example, three other city districts (Hägersten, Liljeholmen and Älvsjö) have joined the project, and during our study period, the four districts shared the facilities in Skärholmen.

In 1998, the city district of Skärholmen began to apply a method that has since become known as "the Skärholmen model". During the first year, the activities were only directed to students who were unemployed during the summer, but in 1999, the program was extended to include all unemployed recipients of welfare benefits. When welfare applicants enter the welfare services office, those whose main motivation for applying for welfare is categorized as "unemployment" are immediately sent to "The Job Center" (the local employment agency that administers the job-seeking activities for welfare recipients). Usually, the applicants must meet with Job center personnel before their application is processed. Sometimes the applicant is given suggestions on jobs to seek or other activities on their first visit to the Job center. As long as a person has not found a job or an activity to participate in, the program requires three hours of daily attendance at the Job center, either in the morning or in the afternoon. Every second week the schedule rotates in order to prevent black market work. The central component in the model is job-seeking activities. These are facilitated by providing job seekers with an individual labor market coach and material that may be helpful in the job search, such as computers, telephones and stationery. In addition to job-seeking activities, the program involves participation in internships, short-term education such as computer courses, and other activities arranged by the city district, such as gardening or cleaning in the community. As noted by Thorén (2005), many of the activities aim at testing the participants' willingness to work. There is also a large amount of cooperation

\footnotetext{
${ }^{16}$ Blomberg et al. (2006) study the activation programs implemented in six city districts (Vantör, Skärholmen, Kista, Hässelby-Vällingby, Rinkeby and Spånga-Tensta) and conclude that the programs are similar in many respects. For example, all districts have reception offices from which the welfare applicants are directed to activation centers. At these centers, a mix of the following activities takes place: unassisted job search, assisted job search, internships, work practice, and job guidance.
} 
between the welfare office and the coaches at the Jobcentre. Not participating actively at the Jobcentre will be reported to the welfare administrator, who can decline to provide the recipients their welfare benefits.

The data from the questionnaire are combined with individual register data from Statistics Sweden. The register data contain yearly information on all individuals aged 18-64 living in the municipality of Stockholm during the years 1993 through 2003. Table 2 reports summary statistics on the variables used in this paper. In order to measure the effects on welfare participation, we use a dummy (Welfare recipient) that indicates whether the individual lives in a household that received welfare during the year. ${ }^{17}$ We see from Table 2 that this is true for approximately 9 percent of all individuals in our sample. A potential problem with this measure of welfare participation is that it is quite crude in the sense that an individual is considered as being a welfare participant if he or she has received some welfare benefits at some point during a year. However, the amount received differs substantially between individuals, and it is therefore also interesting to investigate the effect on the amount of welfare money received during a year (Welfare benefits). ${ }^{18}$ The average amount received is approximately 2,000 SEK per year. This might seem like a low figure, but note that individuals receiving no welfare are included. For those individuals who did receive some welfare, the average amount received is approximately 22,300 SEK.

Since we are interested in what happens to individuals who potentially leave welfare or refrain from entering into welfare, we will also investigate the effects on employment. We use four different measures of employment: A dummy indicating whether the individual worked at least 1 hour in November (Employed in November), a dummy indicating whether the individual was employed all 12 months (Employed all year), a variable that measures how many months the individual was employed in the year (Months employed), and income earned from employment (Income from employment). In the variables Employed all year and Months Employed, an individual

\footnotetext{
${ }^{17}$ Welfare benefits are directed to households, not individuals. For simplicity, we will in the rest of the paper write as if it was the individual who received welfare. What we mean is, however, whether the individual lived in a household that received welfare.

${ }^{18}$ The variable "Welfare benefits" is the individual's share of the household's welfare benefits.
} 
was defined as employed if the work performed that month generated an income larger than 25 percent of the minimum wage of workers in the hotel and restaurant sector. Summary statistics for the different employment measures are reported in Table 2. Approximately 74 percent of the population is employed according to the first definition.

Finally, we will investigate what happens to the economic well-being of individuals by investigating effects on disposable income. As we can see from the table below, disposable income varies substantially between individuals.

In the empirical analysis, we will also control for a number of individual specific characteristics; summary statistics for those variables are also provided in Table $2 .^{19}$

Table 2 Summary statistics

\begin{tabular}{|c|c|c|c|c|}
\hline Variable & Mean & Std. Dev. & Min & Max \\
\hline \multicolumn{5}{|l|}{ Outcome variables } \\
\hline The probability of receiving welfare & 0.089 & 0.285 & 0 & 1 \\
\hline Welfare benefits & 2,004 & 9,571 & 0 & 510,800 \\
\hline Employed in November & 0.737 & 0.440 & 0 & 1 \\
\hline Employed all year & 0.650 & 0.477 & 0 & 1 \\
\hline Months employed & 8.542 & 5.136 & 0 & 12 \\
\hline Income from employment & 164,234 & 170,712 & 0 & $25,977,500$ \\
\hline Disposable income* & 158,138 & 266,384 & $-1,551,500$ & $223,910,800$ \\
\hline \multicolumn{5}{|l|}{ Control variables } \\
\hline Woman & 0.499 & 0.500 & 0 & 1 \\
\hline Age 18-25 & 0.151 & 0.358 & 0 & 1 \\
\hline Age $26-35$ & 0.262 & 0.440 & 0 & 1 \\
\hline Age $36-45$ & 0.357 & 0.479 & 0 & 1 \\
\hline Age $46-64$ & 0.231 & 0.421 & 0 & 1 \\
\hline With young children ( $<7$ years) & 0.184 & 0.387 & 0 & 1 \\
\hline Born in Sweden & 0.776 & 0.417 & 0 & 1 \\
\hline Born in Nordic country & 0.047 & 0.211 & 0 & 1 \\
\hline Born in Western country & 0.025 & 0.156 & 0 & 1 \\
\hline Born in East European country & 0.036 & 0.186 & 0 & 1 \\
\hline Born in other country & 0.120 & 0.325 & 0 & 1 \\
\hline Elementary school< 9 years & 0.204 & 0.403 & 0 & 1 \\
\hline Elementary school 9 years & 0.259 & 0.438 & 0 & 1 \\
\hline High school & 0.197 & 0.398 & 0 & 1 \\
\hline College/University<2 years & 0.165 & 0.371 & 0 & 1 \\
\hline College/University $>2$ years & 0.166 & 0.372 & 0 & 1 \\
\hline $\mathrm{Ph} D$ & 0.009 & 0.095 & 0 & 1 \\
\hline Immigration 2-4 years ago & 0.017 & 0.131 & 0 & 1 \\
\hline Immigration 5-9 years ago & 0.050 & 0.217 & 0 & 1 \\
\hline Immigration $10-14$ years ago & 0.045 & 0.207 & 0 & 1 \\
\hline Immigration $>15$ years ago or not at all & 0.888 & 0.315 & 0 & 1 \\
\hline 1 child & 0.201 & 0.401 & 0 & 1 \\
\hline More than 1 child & 0.203 & 0.402 & 0 & 1 \\
\hline
\end{tabular}

* Only available for the years 1995-2003. 
The city districts are rather heterogeneous with respect to demographic composition and outcome variables, as illustrated by Table 3, which presents summary statistics from 1993 on some of the outcome variables as well as the share of the population that was foreign born.

Table 3 City district characteristics in 1993

\begin{tabular}{|c|c|c|c|c|c|}
\hline & $\begin{array}{r}\text { Share welfare } \\
\text { recipients }\end{array}$ & $\begin{array}{c}\text { Average } \\
\text { welfare } \\
\text { benefits }\end{array}$ & $\begin{array}{r}\text { Share employed } \\
\text { (November) }\end{array}$ & $\begin{array}{r}\text { Average } \\
\text { disposable income* }\end{array}$ & $\begin{array}{r}\text { Share of } \\
\text { foreign born } \\
\text { individuals }\end{array}$ \\
\hline Bromma & 0.06 & 1,087 & 0.76 & 149,045 & 0.12 \\
\hline Enskede-Årsta & 0.08 & 1,525 & 0.73 & 129,633 & 0.16 \\
\hline Farsta & 0.13 & 2,431 & 0.70 & 124,991 & 0.17 \\
\hline Hägersten & 0.08 & 1,449 & 0.73 & 130,481 & 0.15 \\
\hline Hässelby-Vällingby & 0.08 & 1,288 & 0.74 & 137,476 & 0.15 \\
\hline Kista & 0.19 & 3,847 & 0.67 & 120,446 & 0.42 \\
\hline Liljeholmen & 0.10 & 1,922 & 0.71 & 122,920 & 0.16 \\
\hline Skärholmen & 0.13 & 2,092 & 0.66 & 119,657 & 0.32 \\
\hline Vantör & 0.14 & 2,606 & 0.68 & 120,665 & 0.20 \\
\hline Spånga-Tensta & 0.17 & 3,209 & 0.64 & 124,431 & 0.42 \\
\hline Älvsjo & 0.07 & 1,050 & 0.76 & 140,942 & 0.14 \\
\hline
\end{tabular}

Comparing the figures in Table 3 with the year of program implementation shown in Table 1, it is worth noting that the city districts with the highest welfare participation seem to have implemented the policy first. In the next section, we will discuss how this is taken into account in the empirical analysis.

\section{Econometric strategy}

When investigating the effect of a specific policy on individual behavior, the econometric challenge is to separate effects of the policy from other factors that also may affect individual behavior. If one only compares the behavior of an individual before and after a policy change, there is a major risk that one also captures differences in the behavior that depend on factors other than the policy. One way to isolate the effect of the policy from all other things that may affect individual behavior is to

\footnotetext{
${ }^{19}$ Exact definitions of all variables as well as data sources are given in Appendix C.
} 
compare the changes in behavior of individuals residing in a city district that has implemented the policy with changes in the behavior of individuals residing in a city district that has not implemented the policy, thereby netting out other factors that may affect individual behavior. We will use this difference-in-differences approach in this paper.

The identifying assumption for this model is that if the policy had not been implemented, welfare caseloads in the city district that implemented the policy would have changed in the same way as in the city districts that did not implement the policy. As mentioned above, the city districts implemented the policy at different times. The labor market in these years (1998-2003) was somewhat turbulent, with decreasing unemployment rates until 2001 followed by a small increase. Barth et al. (2004, 2006) have shown that labor market conditions matter differently for different groups; i.e., the weaker the group is with respect to labor market attachment, the more sensitive the group is to fluctuations in labor market conditions. Given that the city districts with the potentially weakest groups were those that implemented mandatory activation first, one might worry that not taking this into account would put the identifying assumption at risk. In order to avoid this potential problem, we will control for a number of specific individual characteristics and also allow the coefficients for these characteristics to have different effects over time. By doing this, we control for the fact that a specific demographic structure in the early years may affect welfare caseloads differently than having the same demographic structure in the later years, when the labor market conditions differ. ${ }^{20}$

Even after controlling for demographics in the flexible way described above, there might be different time trends in the different city districts. We will therefore also allow for linear, city-district-specific time trends. The equation that forms the basis for our empirical analysis is given by

\footnotetext{
20 If welfare-prone individuals move between city districts depending on whether or not the districts have implemented strict mandatory activation programs, we might be worried that equation (3) captures these effects rather than effects on welfare participation. However, Edmark (2007) does not find that the moving patterns of welfare-prone individuals differ from the moving patterns of non-welfare-prone individuals.
} 


$$
Y_{i j t}=\alpha_{j}+\tau_{t}+\text { Bprogram }_{j t}+\theta_{t} X_{i j t}+\text { trend }_{j}+\varepsilon_{i j t} .
$$

where $Y_{i j t}$ is the outcome of interest for individual $i$ in city district $j$ in time period (year) $t, \alpha_{j}$ are city-district-specific fixed effects, $\tau_{t}$ are time-specific fixed effects that are common for all city districts, program $_{j t}$ is an indicator variable that takes the value 1 if the policy is implemented in city district $j$ in year $t$ (and all years thereafter), $X_{i j t}$ is a vector of demographic covariates, trend $_{j}$ are city-district-specific time trends, and $\varepsilon_{i j t}$ are error terms.

One thing that equation (1) does not control for is unobserved city-district-specific shocks that might vary over time. If such shocks exist, they might cause two different kinds of problems. First, if the shocks are correlated with the timing of the reform, $\beta$ might capture these shocks rather than true program effects. Second, such shocks might imply that the standard errors of individuals within the same city district will be correlated, making the estimated standard errors biased and thereby invalidating inference.

Since we focus on city districts within a close geographical distance that also make up the center of a much larger labor market region, we believe that we are likely to capture any such shocks with the common time effect together with the time-varying coefficient on the control variables. However, to examine whether there still exists any correlation within the residuals that makes inference problematic, we will conduct the test suggested by Wooldridge (2003). He suggests initially restricting the unobserved city-district-specific shocks to zero and then solving for $\beta$ using the minimum distance (MD) estimator. The efficient MD estimator is obtained by estimating the following model:

$$
Y_{i j t}=q_{j t}+\theta_{t} X_{i j t}+\eta_{i j t}
$$

and then using the predicted $\hat{q}_{j t}$ from equation (2), estimating equation (3) using weighted least squares: 


$$
\hat{q}_{j t}=\alpha_{j}+\tau_{t}+\beta \text { program }_{j t}+\text { trend }_{j}+\mu_{j t}
$$

where the weights are given by $1 / \hat{\sigma}_{j t}^{2}$, $\hat{\sigma}_{j t}$ being the estimated standard errors for $q_{j t}$ from the estimation of equation (2), and where $\eta_{i j t}$ and $\mu_{j t}$ are error terms. Under the null of no unobserved city-specific time shocks, $S S R_{w} \stackrel{a}{\sim} \chi^{2}(S-K)$, where $S$ is given by $J \times T$ and $K$ is the number of estimated parameters in (3). If $H_{0}$ is rejected, then Wooldridge proposes to instead use the two-step estimator suggested by Donald and Lang (2007). This two-step estimator is conducted by estimating (2) and (3), but in this case, the weights for (3) are given by the population shares of the different city districts.

As a further sensitivity check, we will also conduct a placebo experiment where we pretend that the programs took effect five years before their actual implementation and then estimate the effects of these placebo programs using data from the pre-reform period, i.e., before any city district had implemented any program. Furthermore, we will investigate whether any pre-program effects exist, in which case we might suspect that the treatment is not exogenous conditioning on controls. If we find an effect of the true timing of the reform, but no effect for the placebo reform or pre-program effects, we will be more confident that we have in fact captured relevant differences in the citydistricts with our model specification, thus finding the true program effect.

\section{Average effects of mandatory activation}

In this section, we will first estimate the baseline DD-estimates of the effects of mandatory activation on welfare, employment and disposable income. Thereafter, we will conduct some placebo experiments in order to validate that we have indeed estimated treatment effects.

\subsection{Effects on welfare participation}

According to the theoretical prediction from the Besley and Coate (1992) model, welfare participation should decrease as a consequence of the introduction of mandatory activation programs. Table 4 presents the effect of mandatory activation on the 
probability for an individual to receive welfare sometime during a year as well as the amount received (including zeros). We use a linear probability model, controlling for several observed as well as unobserved characteristics of the city districts. In the first two columns, we estimate the model using individual level data, thereby ignoring any city-district-specific time shocks. Doing this, we find that the probability that the household receives welfare decreases by 0.4 percentage points when mandatory activation is implemented. This corresponds to a 4.5 percent decrease at the mean value. Also, the amount received decreases by almost 80 SEK per year. This corresponds to a decrease of 3.6 percent at the mean value.

Whether or not it is possible to draw a correct inference from the estimated standard errors depends on whether there are any city-district-specific time shocks that we have not controlled for. We test this along the lines suggested by Wooldridge (2003). The resulting test statistic is given in the third line from the bottom in the table. Since the critical value at the 10 percent significance level is 106.5 , we must reject the null of no city-district-specific shocks. We therefore turn to the Donald and Lang estimates presented in columns (3) and (4). They show that mandatory activation decreases welfare participation, but that the effect is only statistically significant (at the 10 percent level) for the probability of receiving welfare. For the benefit level, the effect is statistically significant at the 20 percent level. These results indicate that mandatory activation may reduce welfare participation, but no strong conclusion can be drawn due to the large standard errors. 
Table 4 Effects on welfare participation

\begin{tabular}{lrrrr}
\hline & $(1)$ & $(2)$ & $(3)$ & $(4)$ \\
\hline & & Individual level data & \multicolumn{2}{c}{ Donald and Lang estimator } \\
\hline & Prob. of receiving & Welfare benefits, & Prob. of receiving & Welfare benefits, \\
& welfare & SEK & welfare & SEK \\
\hline Treatment effect & $-0.004^{\star \star \star}$ & $-79.5^{\star \star}$ & $-0.005^{\star}$ & -97.0 \\
& $(0.001)$ & $(34.2)$ & $(0.003)$ & $(80.82)$ \\
\hline Wooldridge test: & & & & \\
SSR $_{\mathrm{w}}$ (df) & $529.2(89)$ & $285.8(89)$ & & 121 \\
\hline R-squared & 0.15 & 0.10 & 121 & \\
No. of obs. & $2,535,573$ & $2,535,573$ & & \\
\hline
\end{tabular}

Notes: Robust standard errors in parentheses. ${ }^{* * *},{ }^{* *}$, and $*$ denote significance at 1,5 and 10 percent levels, respectively. Standard errors in columns (1) and (2) are clustered at the household level. The estimated models include city district fixed effects, time effects, individual characteristics (gender, education level, immigration year, region of birth, children and age), time varying parameters on covariates and district specific time trends.

\subsection{Effects on employment}

In this section, we will examine the effects of activation programs on employment. ${ }^{21}$ We use four different variables to capture effects on employment. The first is a dummy taking the value one if the individual was employed in November in a given year and zero otherwise. The second is the number of months that the individual has been employed during a year. The third is a dummy indicating whether an individual has been employed all 12 months of the year, and the fourth is income from employment. The results are presented in Table 5. Regardless of which employment measure we use, we find that mandatory activation increases employment. Starting with the November measure, we find that mandatory activation increases the individual's probability of being employed by 0.4 percentage points, which corresponds to an increase of 0.5 percent. Furthermore, the number of months that the individual is employed increases by 0.04 months ( 1 percent), and the probability that the individual is employed for the full year increases by 0.3 percentage points ( 0.5 percent). Finally, income from employment increases by 1,283.4 SEK per year, which corresponds to 0.8 percent of the mean value in the sample.

Based on the Wooldridge test, we cannot reject the null of no city-district-specific time shocks. Since all city districts are centered in the middle of the same labor market region, this result is as expected. Hence, we do not need to turn to the Donald and Lang 
(2007) estimator, instead using individual level data for inference. Doing this, we conclude that all estimates are statistically significant.

Table 5 Effects on employment

\begin{tabular}{|c|c|c|c|c|}
\hline & (1) & (2) & (3) & (4) \\
\hline & $\begin{array}{r}\text { The probability of } \\
\text { employment in } \\
\text { November }\end{array}$ & $\begin{array}{r}\text { The number of } \\
\text { months employed }\end{array}$ & $\begin{array}{l}\text { The probability of } \\
\text { being employed } \\
\text { for the full year }\end{array}$ & $\begin{array}{r}\text { Individual level data } \\
\text { Income from } \\
\text { employment }\end{array}$ \\
\hline Treatment effect & $\begin{array}{r}0.004^{\star \star \star} \\
(0.001) \\
\end{array}$ & $\begin{array}{r}0.041^{\star \star \star} \\
(0.015) \\
\end{array}$ & $\begin{array}{l}0.003^{\star \star} \\
(0.001)\end{array}$ & $\begin{array}{r}1,283.4^{\star \star \star} \\
(397.1) \\
\end{array}$ \\
\hline $\begin{array}{l}\text { Wooldridge test: } \\
\text { SSR }_{\mathrm{w}}(\mathrm{df})\end{array}$ & $72.2(89)$ & 86.8 (89) & $97.2(89)$ & 56.9 (89) \\
\hline $\begin{array}{l}\text { R-squared } \\
\text { No. of obs. }\end{array}$ & $\begin{array}{r}0.13 \\
2,535,573 \\
\end{array}$ & $\begin{array}{r}0.14 \\
2,535,573\end{array}$ & $\begin{array}{r}0.14 \\
2,535,573\end{array}$ & $\begin{array}{r}0.23 \\
2,535,573 \\
\end{array}$ \\
\hline $\begin{array}{l}\text { Notes: Robust stal } \\
10 \text { percent levels, } \\
\text { characteristics (gel }\end{array}$ & $\begin{array}{l}\text { ors clustered on hc } \\
\text { vely. The estimat } \\
\text { cation level, immi }\end{array}$ & $\begin{array}{l}\text { olds in parentheses } \\
\text { odels include city } \\
\text { on year, region of b }\end{array}$ & $\begin{array}{l}* * \text {, and } * \text { denote } \\
\text { rict fixed effects, } \\
\text { children and age), }\end{array}$ & $\begin{array}{l}\text { significance at } 1,5 \text { and } \\
\text { time effects, individual } \\
\text { time varying parameters }\end{array}$ \\
\hline
\end{tabular}

\subsection{Effects on economic well-being}

Another interesting question is how well the individuals are doing in economic terms. Thanks to reliable register-based information on individuals' disposable income ${ }^{22}$, we are able to analyze this, something that has not been done in earlier studies on U.S. welfare reform when relying on observational data. ${ }^{23}$ From the results, presented in Table 6, it is clear that the introduction of mandatory activation leads to a significant net increase in disposable income of 1,947 SEK. However, the Wooldridge test rejects the null of no city-district-specific shocks ${ }^{24}$, and the standard errors for the Donald and Lang estimator are large. Therefore, we must conclude that we cannot find any statistically significant effects of mandatory activation on disposable income.

\footnotetext{
${ }^{21}$ The predictions from the Besley and Coate (1992) model are not explicit about outcomes other than welfare participation, but implicitly there is an understanding that mandatory activation should have a positive effect on the employment rate and, possibly, other labor market outcomes.

${ }^{22}$ Disposable income is defined as all income received (from work, social security systems, transfers, etc.) minus taxes and other payments (such as study loan payments).

${ }^{23}$ The income data available in the U.S. are self-reported and, as is discussed in Meyer and Sullivan (2003), income therefore tends to be underreported, especially by welfare recipients. Using consumption data instead, Meyer and Sullivan (2004) examine the material conditions of single mothers and their families to assess the net effect of the U.S. welfare reforms on the well-being of these families. They find that the material conditions of single mothers have not declined either in absolute terms or relative to different comparison groups (such as single childless women).

${ }^{24}$ The critical value at the ten percent level is 114.1 .
} 
Table 6 Effects on disposable income

\begin{tabular}{lrr}
\hline & $(1)$ & $(2)$ \\
\hline Treatment effect & Individual level data & Donald-Lang estimator \\
\hline Wooldridge test: & $1,947^{\star * \star}$ & 1,929 \\
SSR $_{\mathrm{W}}$ (df) & $(750.6)$ & $(2,197)$ \\
\hline R-squared & & \\
No. of observations & $129.0(69)$ & 88 \\
\hline
\end{tabular}

Notes: Robust standard errors in parentheses. ${ }^{* * *}{ }^{* *}$, and * denote significance at 1,5 and 10 percent levels, respectively. Standard errors in columns (1) and (2) are clustered at the household level. The estimated models include city district fixed effects, time effects, individual characteristics (gender, education level, immigration year, region of birth, children and age), time varying parameters on covariates and district specific time trends.

\subsection{Placebo-experiment}

In order to investigate whether the estimated effects in the analysis above are indeed program effects, we will next conduct a placebo experiment. If we do not find any effect of this placebo reform, we will be more confident that the estimated effect is in fact a program effect and not just an unobserved city-district-specific shock.

In the placebo experiment, we use data from the period 1993-98, i.e., the period before any mandatory activation program had been put in place in any city district. In order to create placebo reforms, we pretend that the programs were implemented five years before they actually were. Hence, we pretend that Skärholmen implemented the program in 1994 and that Farsta and Kista followed in 1996, etc. We then estimate the same model as in sections 6.3-6.4. Doing this, we obtain the results presented in Table 7.

Table 7 Placebo-experiment

\begin{tabular}{lrr}
\hline & "True reform" & "Placebo-reform" \\
\hline Prob. of receiving welfare & $-0.004^{\star \star \star}$ & -0.001 \\
& $(0.001)$ & $(0.001)$ \\
Welfare benefits, SEK & $-79.5^{\star \star}$ & -1.1 \\
& $(34.2)$ & $(32.8)$ \\
The probability of employment in November & $0.004^{\star \star \star}$ & -0.000 \\
& $(0.001)$ & $(0.001)$ \\
The number of months employed & $0.041^{\star \star \star}$ & 0.008 \\
& $(0.015)$ & $(0.016)$ \\
The probability of being employed full year & $0.003^{\star \star}$ & 0.001 \\
& $(0.001)$ & $(0.002)$ \\
Income from employment & $1,283.4^{\star \star *}$ & 77.9 \\
& $(397.1)$ & $(300.6)$ \\
\hline Notes: Robust standard errors clustered on households in parentheses. ${ }^{* * *}, * *$, and $*$ denote significance at 1,5 and \\
10 percent levels, respectively. The estimated models include city district fixed effects, time effects, individual \\
characteristics (gender, education level, immigration year, region of birth, children and age), time varying parameters \\
on covariates and district specific time trends.
\end{tabular}


Comparing the "true reform" estimates with the estimates for the placebo reform, we can conclude that all estimates for the latter are statistically insignificant. Hence, we cannot reject that the effects of the placebo reforms are zero. Furthermore, all of the point-estimates are small and close to zero. These findings strengthen our belief that mandatory activation affects employment and possibly also welfare participation.

Another way to investigate if we have captured true program effects or if the results depend on some trend that we have not adequately controlled for is to - in addition to the treatment indicator in equation (1) - also include dummies for the years preceding the implementation of the programs.

Table 8 shows the results of these estimations, allowing for the reform to have some effect already two years before the programs were introduced. For most of the outcome variables (four out of six), we do not find any statistically significant estimates for the two years preceding the programs. Also, the point estimates are all much lower than the point estimate for the program period. For the probability of receiving welfare and for the number of months employed, we find some statistically significant effects in the period before the program starts. However, the point-estimates are considerably lower than for the actual reform year. We take this as further evidence that we have in fact captured true program effects.

Table 8 Effects in the years before program implementation

\begin{tabular}{lrrrrrr}
\hline & $\begin{array}{l}\text { Welfare } \\
\text { recipient }\end{array}$ & $\begin{array}{r}\text { Welfare } \\
\text { benefits }\end{array}$ & $\begin{array}{r}\text { Prob. of } \\
\text { employed in } \\
\text { November }\end{array}$ & $\begin{array}{r}\text { The number } \\
\text { of months } \\
\text { employed }\end{array}$ & $\begin{array}{r}\text { Prob. of } \\
\text { employed } \\
\text { full year }\end{array}$ & $\begin{array}{r}\text { Income from } \\
\text { employment }\end{array}$ \\
\hline $\mathrm{t}$ & $-0.006^{\star *}$ & $-116.0^{*}$ & $0.005^{*}$ & $0.0736^{\star \star *}$ & $0.004^{*}$ & $1,095.8$ \\
$\mathrm{t}-1$ & $(0.002)$ & $(53.9)$ & $(0.002)$ & $(0.0248)$ & $(0.002)$ & $(652.7)$ \\
& $-0.004^{*}$ & -70.6 & 0.002 & $0.0353^{*}$ & 0.001 & -211.8 \\
$\mathrm{t}-2$ & $(0.001)$ & $(43.3)$ & $(0.002)$ & $(0.0197)$ & $(0.002)$ & $(497.2)$ \\
& 0.001 & 9.4 & 0.000 & $0.0278^{*}$ & 0.001 & -148.5 \\
\hline R-squared & $(0.001)$ & $(33.6)$ & $(0.001)$ & $(0.0155)$ & $(0.001)$ & $(376.2)$ \\
No. of obs. & 0.153 & 0.100 & 0.133 & 0.140 & 0.147 & 0.231 \\
\hline & $2,535,573$ & $2,535,573$ & $2,535,573$ & $2,535,573$ & $2,535,573$ & $2,535,573$ \\
\hline
\end{tabular}




\section{$6 \quad$ Are the effects sluggish?}

It could be the case that it takes some time before the programs start to have effects on welfare and employment if, for example, the programs have some start-up period before they are fully implemented, or if it takes time before inhabitants realize that the social assistance office demands activation. If so, we would expect the effects of mandatory activation to increase over time. In order to investigate this, we have estimated a more dynamic version of the model including two additional indicators, one indicator taking the value one the year after the reform and afterwards and zero otherwise, and the other indicator taking the value one two years after the reform and afterwards. These results are given in Table 9. A statistically significant estimate for $t+1$ or $t+2$ should be interpreted as the effect being larger the year after/two years after the reform. As is clear from the table, the full effects are already in effect in the year of implementation.

Table 9 Are the effects sluggish?

\begin{tabular}{lrrrrrr}
\hline & $\begin{array}{r}\text { Welfare } \\
\text { recipient }\end{array}$ & $\begin{array}{r}\text { Welfare } \\
\text { benefits }\end{array}$ & $\begin{array}{r}\text { Prob. of } \\
\text { employment } \\
\text { in } \\
\text { November }\end{array}$ & $\begin{array}{r}\text { The number } \\
\text { of months } \\
\text { employed }\end{array}$ & $\begin{array}{r}\text { The prob. of } \\
\text { being } \\
\text { employed } \\
\text { full year }\end{array}$ & $\begin{array}{r}\text { Income from } \\
\text { employment }\end{array}$ \\
\hline $\mathrm{t}$ & $-0.005^{\star *}$ & $-81.4^{*}$ & $0.004^{\star \star}$ & $0.0457^{\star \star \star}$ & $0.00433^{\star \star \star}$ & $1,370.2^{\star \star}$ \\
& $(0.001)$ & $(32.5)$ & $(0.001)$ & $(0.0151)$ & $(0.00146)$ & $(395.9)$ \\
$\mathrm{t}+1$ & 0.001 & 6.5 & 0.001 & -0.0154 & $-0.00356^{\star \star}$ & -317.8 \\
& $(0.001)$ & $(36.6)$ & $(0.002)$ & $(0.0170)$ & $(0.00168)$ & $(414.9)$ \\
$\mathrm{t}+2$ & -0.001 & 2.7 & 0.001 & -0.0271 & -0.00227 & 383.7 \\
& $(0.002)$ & $(49.8)$ & $(0.002)$ & $(0.0217)$ & $(0.00207)$ & $(511.9)$ \\
\hline R-squared & 2535573 & 2535573 & 2535573 & 2535573 & 2535573 & 2535573 \\
No. of obs. & 0.153 & 0.100 & 0.133 & 0.140 & 0.147 & 0.231 \\
\hline
\end{tabular}

Notes: Robust standard errors clustered on households in parentheses. ${ }^{* * *}{ }^{* *}$, and ${ }^{*}$ denote significance at 1,5 and 10 percent levels, respectively. The estimated models include city district fixed effects, time effects, individual characteristics (gender, education level, immigration year, region of birth, children and age), time varying parameters on covariates and district specific time trends.

\section{Does mandatory activation affect vulnerable groups differently?}

So far we have estimated average effects. However, as is shown by Table 10, there are certain groups for whom welfare participation is especially high, i.e., younger people, those born outside Sweden (in particular, those born in non-Western areas, i.e., Asia, Africa and Latin America), and families with children, especially those with a single 
parent. It is therefore of interest to investigate whether the mandatory activation programs have different effects for these groups. Also, welfare might be extra harmful for young people or immigrants due to, e.g., scarring effects, making it especially important to understand how to decrease welfare participation in these groups. ${ }^{25}$ In this section, we will investigate whether the effects of mandatory activation are heterogeneous with respect to family status, age and country of origin. We do this by extending the baseline model in equation (1) with interaction terms between the variable indicating whether a mandatory activation program had been introduced in a given city district in a given year (i.e., the program variable) and the socioeconomic variable of interest (family status, age, or country of origin). In the tables, we present the coefficients for the program variable (i.e., the difference-in-differences estimate) and the coefficients for the interaction variables. To save space, we do not report the results for the probability of being employed for the full year, and given the results of the sensitivity analysis, we refrain from estimating heterogeneous effects for disposable income.

\footnotetext{
${ }^{25}$ Skans (2004) shows that experiencing unemployment subsequent to graduation from high school has negative effects on both unemployment and earnings at least five years after graduation, whereas Åslund and Rooth (2007) show that exposure to high local unemployment rates affects immigrants for at least ten years after entry to Sweden.
} 
Table 10 Welfare participation among different groups

\begin{tabular}{|c|c|c|c|c|c|c|}
\hline & \multirow{2}{*}{$\begin{array}{l}\text { Welfare } \\
\text { recipient }\end{array}$} & \multirow{2}{*}{$\begin{array}{l}\text { Welfare } \\
\text { benefits }\end{array}$} & \multicolumn{3}{|c|}{ Employment } & \multirow{2}{*}{$\begin{array}{r}\text { Income } \\
\text { from work }\end{array}$} \\
\hline & & & November & Months & All year & \\
\hline All & 0.089 & 2,004 & 0.737 & 8.542 & 0.650 & 164,234 \\
\hline Age & & & & & & \\
\hline $\begin{array}{l}18-25 \\
\text { Country of birth }\end{array}$ & 0.14 & 2,494 & 0.565 & 6.272 & 0.377 & 78,720 \\
\hline $\begin{array}{l}\text { Born in Nordic } \\
\text { country }\end{array}$ & 0.095 & 2,223 & 0.711 & 8.318 & 0.649 & 146,126 \\
\hline $\begin{array}{l}\text { Born in Western } \\
\text { country }\end{array}$ & 0.062 & 1,311 & 0.598 & 6.956 & 0.533 & 125,532 \\
\hline $\begin{array}{l}\text { Born in East } \\
\text { Europe }\end{array}$ & 0.157 & 4,241 & 0.575 & 6.615 & 0.494 & 109,686 \\
\hline $\begin{array}{l}\text { Born in other } \\
\text { country } \\
\text { Family status }\end{array}$ & 0.294 & 7,250 & 0.512 & 5.877 & 0.411 & 84,201 \\
\hline $\begin{array}{l}\text { Cohabiting } \\
\text { parents with } \\
\text { small children }\end{array}$ & 0.090 & 1,413 & 0.806 & 9.056 & 0.702 & 176,020 \\
\hline $\begin{array}{l}\text { Single parent- } \\
\text { households with } \\
\text { small children }\end{array}$ & 0.319 & 5,953 & 0.621 & 6.841 & 0.493 & 90,333 \\
\hline
\end{tabular}

\subsection{Family status}

We begin by examining whether mandatory activation has different effects on families with children under the age of 7 . We have separate indicators for single parents and cohabiting parents. From the results, presented in Table 11, it appears that mandatory activation typically does not have any significantly different effects on single parents with young children. The same goes for cohabiting parents with young children, except for the monetary outcomes "welfare benefits" and "income from work". While mandatory activation reduces welfare benefits for two-parent families by almost 700 SEK, there are no significant effects for single-parent households or households without young children. On the other hand, mandatory activation has a negative effect on income from work for cohabiting parents with young children, while for the other groups it has a significantly positive effect. A possible explanation for the differences in the effects on income might be that those no longer receiving welfare benefits in families with two adults become dependent on the income of their partner instead of turning to paid work. 
Table 11 Heterogeneous effects with respect to family status

\begin{tabular}{|c|c|c|c|c|c|}
\hline & Welfare recipient & $\begin{array}{r}\text { Welfare } \\
\text { benefits, SEK }\end{array}$ & $\begin{array}{r}\text { Employed in } \\
\text { November }\end{array}$ & $\begin{array}{r}\text { Number of } \\
\text { months } \\
\text { employed }\end{array}$ & $\begin{array}{r}\text { Income from } \\
\text { work, SEK }\end{array}$ \\
\hline DD-estimate & $\begin{array}{r}-0.004 * * * \\
(0.001)\end{array}$ & $\begin{array}{r}31.3 \\
(36.5)\end{array}$ & $\begin{array}{l}0.004^{\star \star} \\
(0.001)\end{array}$ & $\begin{array}{r}0.036^{* *} \\
(0.017)\end{array}$ & $\begin{array}{r}2771.2^{\star \star} \\
(466.2)\end{array}$ \\
\hline $\begin{array}{l}\text { DD- } \\
\text { estimate* Single } \\
\text { parent with young } \\
\text { children }\end{array}$ & $\begin{array}{r}-0.004 \\
(0.007)\end{array}$ & $\begin{array}{r}-386.7 \\
(206.8)\end{array}$ & $\begin{array}{r}-0.011 \\
(0.008)\end{array}$ & $\begin{array}{r}-0.148 * \\
(0.088)\end{array}$ & $\begin{array}{r}2530.0 \\
(2058.8)\end{array}$ \\
\hline $\begin{array}{l}\text { DD-estimate* } \\
\text { Cohabiting } \\
\text { parents with } \\
\text { young children }\end{array}$ & $\begin{array}{r}-0.002 \\
(0.003)\end{array}$ & $\begin{array}{r}-687.9 * * \\
(068.0)\end{array}$ & $\begin{array}{r}0.000 \\
(0.004)\end{array}$ & $\begin{array}{r}0.057 \\
(0.041)\end{array}$ & $\begin{array}{r}-10431.9^{\star *} \\
(1657.8)\end{array}$ \\
\hline R-squared & 0.16 & 0.10 & 0.13 & 0.14 & 0.23 \\
\hline $\begin{array}{l}\text { No. of } \\
\text { observations }\end{array}$ & $2,535,573$ & $2,535,573$ & $2,535,573$ & $2,535,573$ & $2,535,573$ \\
\hline
\end{tabular}

Notes: Robust standard errors clustered on households in parentheses. ${ }^{* * *},{ }^{* *}$, and ${ }^{*}$ denote significance at 1,5 and 10 percent levels, respectively. The estimated models include city district fixed effects, time effects, individual characteristics (gender, education level, immigration year, region of birth, children and age), time varying parameters on covariates and district specific time trends.

\subsection{Age}

Next we examine whether mandatory activation has significantly different effects on young people (aged 18-25). The results are presented in Table 12. While there are no statistically significant differences between the 18-25 year olds and those over 25 years of age when it comes to welfare benefits, there are significant differences between the two groups when it comes to the other outcomes (and the differences are huge when it comes to income from work). Starting with the effects on employment, it seems like mandatory activation has no effects on people aged 26 or older, while it has a positive and significant effect for the younger group. The increase in the probability of being employed in November for the younger group is 0.9 percentage points, which corresponds to a 1.6 percent increase, and the increase in the number of months employed is 0.14 , which corresponds to a 2.2 percent increase. Turning to the income variable, we note that while mandatory activation has a significantly negative effect of 
1,813 SEK on income from work for the older age group, it has a significantly positive effect of 19,223 SEK $(-1,813+21,036)$ for the younger age group, which corresponds to an increase of 25 percent. It thus appears that mandatory activation programs work very well for young adults.

Table 12 Heterogeneous effects with respect to age

\begin{tabular}{|c|c|c|c|c|c|}
\hline & $\begin{array}{l}\text { Welfare } \\
\text { recipient }\end{array}$ & $\begin{array}{l}\text { Welfare } \\
\text { benefits }\end{array}$ & $\begin{array}{r}\text { Employed } \\
\text { in } \\
\text { November }\end{array}$ & $\begin{array}{r}\text { Number of } \\
\text { months } \\
\text { employed }\end{array}$ & $\begin{array}{r}\text { Income from } \\
\text { work }\end{array}$ \\
\hline DD-estimate & $\begin{array}{r}-0.006^{\star \star \star} \\
(0.001)\end{array}$ & $\begin{array}{l}-81.3^{*} \\
(35.2)\end{array}$ & $\begin{array}{r}0.002 \\
(0.001)\end{array}$ & $\begin{array}{r}0.0199 \\
(0.0161)\end{array}$ & $\begin{array}{r}-1,812.9^{* *} \\
(430.0)\end{array}$ \\
\hline $\begin{array}{l}\text { DD-estimate } \\
\text { *Young }(18-25)\end{array}$ & $\begin{array}{r}0.011^{\star * \star} \\
(0.002)\end{array}$ & $\begin{array}{r}12.4 \\
(69.8)\end{array}$ & $\begin{array}{l}0.009^{*} \\
(0.004)\end{array}$ & $\begin{array}{l}0.143^{\star \star \star} \\
(0.0435)\end{array}$ & $\begin{array}{r}21,035.9^{* *} \\
(1,065.8)\end{array}$ \\
\hline $\begin{array}{l}\text { R-squared } \\
\text { No. of obs. }\end{array}$ & $\begin{array}{r}0.15 \\
2,535,573\end{array}$ & $\begin{array}{r}0.10 \\
2,535,573\end{array}$ & $\begin{array}{r}0.13 \\
2,535,573\end{array}$ & $\begin{array}{r}0.14 \\
2,535,573\end{array}$ & $\begin{array}{r}0.23 \\
2,535,573\end{array}$ \\
\hline
\end{tabular}

\subsection{Country of birth}

Finally, we examine whether mandatory activation has significantly different effects on individuals who are born within versus outside Sweden. We have separate indicators for whether the individual is born in a Nordic country, in a Western country (apart from the Nordic ones), in an Eastern European country or in some other country (i.e., from Africa, Asia or Latin America). The DD-estimate in Table 13 then captures the effect on native Swedes. It is interesting to note that mandatory activation does not seem to have any significant effects on native Swedes. It appears that mandatory activation works best for the group with the highest welfare participation; there is a significant and negative effect on welfare benefits for those born in Africa, Asia and Latin America. The welfare benefits received by this group decrease by 527 SEK, which amounts to 7.3 percent of the mean value, while income from work increases by 8,142 SEK (9.7 percent). For those born in a Nordic country, on the other hand, mandatory activation seems to be harmful in the sense that it increases welfare benefits, but on the other hand, it also increases income from work substantially. 
Table 13 Heterogeneous effects with respect to country of birth

\begin{tabular}{|c|c|c|c|c|c|}
\hline & Welfare recipient & $\begin{array}{l}\text { Welfare } \\
\text { benefits }\end{array}$ & $\begin{array}{r}\begin{array}{r}\text { Employed } \\
\text { in } \\
\text { November }\end{array} \\
\end{array}$ & $\begin{array}{r}\text { Number of } \\
\text { months } \\
\text { employed }\end{array}$ & $\begin{array}{r}\text { Income from } \\
\text { work }\end{array}$ \\
\hline DD-estimate & $\begin{array}{r}-0.002^{*} \\
0.001)\end{array}$ & $\begin{array}{r}-1.8 \\
(38.9)\end{array}$ & $\begin{array}{r}0.002 \\
(0.002)\end{array}$ & $\begin{array}{r}0.0203 \\
(0.0189)\end{array}$ & $\begin{array}{r}-966.4 \\
(526.6)\end{array}$ \\
\hline $\begin{array}{l}\text { DD- } \\
\text { estimate*Nordic }\end{array}$ & $\begin{array}{r}0.005 \\
(0.004)\end{array}$ & $\begin{array}{r}442.7^{*} \\
(1895)\end{array}$ & $\begin{array}{r}0.002 \\
(0.008)\end{array}$ & $\begin{array}{r}0.0116 \\
(0.0913)\end{array}$ & $\begin{array}{r}10,624.9 * \star \\
(26523)\end{array}$ \\
\hline DD-estimate* & -0.005 & 19.1 & -0.020 & $-0.237^{*}$ & $-3,367.0$ \\
\hline Western country & $(0.004)$ & (171.8) & $(0.011)$ & $(0.129)$ & $(3,552.6)$ \\
\hline DD-estimate* & -0.001 & -106.6 & $0.017^{\star}$ & 0.145 & $10,331 \cdot 1^{\star \star \star}$ \\
\hline East European & (0.005) & (226.5) & $(0.008)$ & (0.0965) & $(2,534.4)$ \\
\hline DD-estimate* & $-0.014^{\star \star \star}$ & $-527.2^{* *}$ & 0.008 & $0.115^{\star \star}$ & $8,142 \cdot 1^{\text {** }}$ \\
\hline Other country & $(0.003)$ & (128.2) & $(0.004)$ & (0.0495) & $(1,297.1)$ \\
\hline R-squared & 0.15 & 0.13 & 0.13 & 0.14 & 0.23 \\
\hline $\begin{array}{l}\text { No. of } \\
\text { observations }\end{array}$ & $2,535,573$ & $2,535,573$ & $2,535,573$ & $2,535,573$ & $2,535,573$ \\
\hline
\end{tabular}

Notes: Robust standard errors clustered on households in parentheses. ***, **, and * denote significance at 1, 5 and 10 percent levels, respectively. The estimated models include city district fixed effects, time effects, individual characteristics (gender, education level, immigration year, region of birth, children and age), time varying parameters on covariates and district specific time trends.

\section{Conclusions}

In this paper, we have examined whether the introduction of mandatory activation programs has any effects on welfare participation, employment, and disposable income. The theoretical prediction from the Besley and Coate (1992) model is that mandatory activation decreases welfare participation and, implicitly, increases employment. As far as we know, this is the first time that a clear empirical test of the hypothesis that this type of program implies fewer people on welfare has been carried out, taking both entry and exit effects into account.

In order to identify causal effects, we made use of a variation that was generated by the gradual implementation of mandatory activation in the city districts in the municipality of Stockholm. The data are very suitable for examining this question for several reasons. First, the reform was clean in the sense that no other instruments, like time limits or tax credits, were introduced at the same time, allowing us to estimate the direct effects of the programs. Second, the reform was initiated at different points in time in different city districts, making identification easier. Finally, by using data from city districts within a single local labor market, we were able to control for common macroeconomic shocks. 
On average, we found a positive effect on employment (the probability that an individual is employed increases with the introduction of the programs). Also, our results indicate that the introduction of mandatory activation programs decreases welfare participation; the introduction of mandatory activation leads to a 0.4 percentage point reduction in the probability of being a welfare participant (an effect that constitutes approximately 5 percent of the average welfare participation rate in the sample). The results support the prediction from the Besley and Coate (1992) model.

We also found that activation requirements seem to work best for young people and for people born in a non-Western country. These results are of particular interest given the scarring effects of youth unemployment found in Skans (2004). Hence, it seems like the programs work best for the most welfare-prone groups. 


\section{References}

Åslund Olof and Dan-Olof Rooth. 2007. "Do when and where matter? Initial labor market conditions and immigrant earnings”. Economic Journal, 117:422-448.

Barth Erling, Bernt Bratsberg and Oddbjorn Raaum. 2004. ”Identifying earnings assimilation of immigrants under changing macroeconomic conditions”. Scandinavian Journal of Economics, 106: 1-22.

Barth Erling, Bernt Bratsberg and Oddbjorn Raaum. 2006. ”Local unemployment and the relative wages of immigrants: Evidence from the current population surveys”. Review of Economics and Statistics, 88: 243-263.

Benus, Jacob M. and Terry R. Johnson. 1997. "Evaluation of the Maryland unemployment insurance work search demonstration”. Report prepared for Maryland Department of Labor, Battelle Memorial Institute in conjunction with Abt Assoiciates Inc.

Bergmark, Åke. (2000). “Socialbidragen under 1990-talet”, in SOU 2000:40, Välfärd och försörjning.

Besley, Timothy J. and Stephen Coate. 1992. "Workfare vs. welfare: Incentive arguments for work requirements in poverty alleviation programs”. American Economic Review, 82: 249-261.

Black, Dan A., Jeffry A. Smith, Mark C. Berger and Brett J. Noel. 2003. "Is the threat of reemployment services more effective than the services themselves? Evidence from random assignment in the UI system.”. American Economic Review, 93: 13131327.

Blank, Rebecca. 2002. “Evaluating welfare reform in the United States”. Journal of Economic Literature, 40: 1105-1166.

Blomberg, Gustaf, Veronica Ekström and Daniel Rauhut. 2006. "Bidrag och motprestation: en uppföljning av arbetet med arbetslösa socialbidragstagare i sex 
stadsdelsområden i Stockholm stad”. FoU-enheten, Stadsledningskontoret i Stockholms stad.

Bloom, Dan and Charles Michalopoulos. 2001. How welfare and work policies affect employment and income: A synthesis of research. New York: Manpower Demonstration Research Corporation.

Dahl, Espen. 2003, “Does 'workfare’ work? The Norwegian experience”, International Journal of Social Welfare, 12: 274-288.

Donald, Stephen G. and Kevin Lang. 2007. "Inference with difference in differences and other panel data”. The Review of Economics and Statistics, 89: 221-233.

Edmark, Karin. 2007. "Effect of work requirements on welfare migration”. IFAU Working Paper 2007:29.

Ekström, Veronica. 2005. ”Individens eget ansvar och samhällets stöd - En utvärdering av ”Skärholmsmodellen” vid Jobbcentrum Sydväst”. FoU-enheten, Stadsledningskontoret i Stockholms stad.

Giertz, Anders. 2004. Making the poor work. Social assistance and activation programs in Sweden. Lund Dissertations in Social Work, No 19.

Grogger, Jeffrey and Lynn A. Karoly. 2005. Welfare reform. Effects of a decade of change. Massachusetts: Harvard University Press, Cambridge.

Grogger, Jeffrey, Steven J. Haider and Jacob Klerman. 2003. ”Why did the welfare rolls fall in the 1990s? The importance of entry”. American Economic Review, 93: 288292.

Hamilton, Gayle. 2002. "Moving people from welfare to work. Lessons from the National Evaluation of Welfare-to-work strategies”. Report, Manpower Demonstration Research Corporation.

Johansson, Håkan. 2000. “Ungdomar med socialbidrag - ett politiskt problem for 1990talet”, in SOU 2000:40, Välfärd och försörjning.

Johansson, Håkan. 2001. I det sociala medborgarskapets skugga. Rätten till socialbidrag under 1980- och 1990-talen, Lund : Arkiv. 
Meyer, Bruce D. and James X. Sullivan, 2003, ”Measuring the well-being of the poor using income and consumption”, Journal of Human Resources, 38(Supplement): $1180-1220$.

Meyer, Bruce D. and James X. Sullivan. 2004. ”The effects of welfare and tax reform: the material well-being of single mothers in the 1980s and 1990s”. Journal of Public Economics, 88:1387-1420.

Milton, Pia and Reinhold Bergström. 1998. "Uppsalamodellen och socialbidragstagarna. En effektutvärdering”, CUS-rapport 1998:1, The National Board of Health and Welfare.

Moffitt, Robert. 2007, ”Welfare reform: The US experience”. Swedish Economic Policy Review, 14:11-47.

Salonen, Tapio and Rickard Ulmestig. 2004. ”Det nedersta trappsteget - En studie om kommunal aktivering”. Institutet för vårdvetenskap och socialt arbete, Växjö universitet.

SCB. 2005. En longitudinell databas kring utbildning, inkomst och sysselsättning (LOUISE) 1990-2002.

Skans Oskar N. 2004. "Scarring effects of the first labour market experience”, IFAU Working Paper 2004:14.

Thorén, Katatina H. 2005. ”Municipal activation policy: A case study of the practical work with unemployed social assistance recipients”. IFAU Working Paper 2005:20.

Wooldridge Jeffrey M. 2003. “Cluster-sample methods in applied econometrics”. The American Economic Review, 93:133-138 


\section{Appendix A: Map - city districts of Stockholm.}

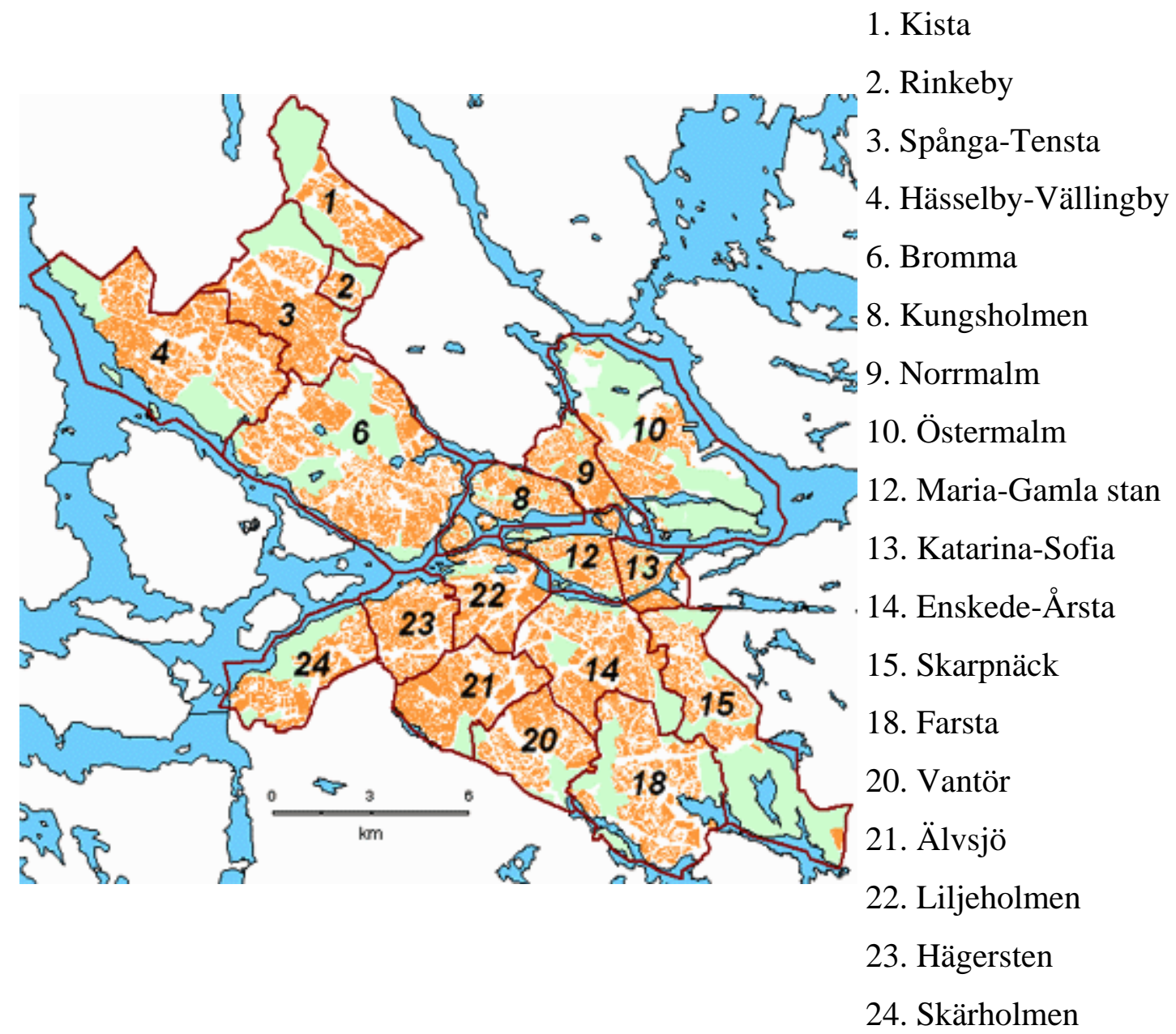




\section{Appendix B: Survey to the social service unit of the city districts of Stockholm}

(Note that the original version is in Swedish and that this is a translated version.)

The survey refers to information on activities for unemployed individuals, capable of working, who receive welfare benefits.

1. Does your city district currently have any activation/labor market related programs for unemployed individuals, capable of working, who receive welfare benefits?

Yes

No

If no, turn to question 9 of the survey.

If yes, please name the program(s):

2. Since what year has the program or programs existed in their current form (under the same or a different name)?

3. Do the program(s) encompass all individuals, capable of working, who are unemployed and receive welfare benefits?

Yes

No

4. If you responded "No" to question 3:

- What percentage of all individuals, capable of working, who are unemployed and receive welfare benefits are served by the program(s)?

- Which groups of individuals are targeted by the program(s)? 
5. Please specify how and to what extent the following activities are being used in the $\operatorname{program}(\mathrm{s})$ :

a. Job-seeking activities

b. Job training activities

c. Other assigned work (for example, within the municipal services)

d. Other activities - please specify which:

6. What is the minimum number of hours of weekly attendance that is required in the $\operatorname{program}(\mathrm{s})$ ?

7. Is absence/non-attendance systematically reported to the social service officials?

Yes

No

Comments:

8. Can absence/non-attendance (without acceptable motives) lead to rejection of the welfare benefit application?

Yes

No

Comments:

In the following part of the survey, we ask for information on programs that were targeted to unemployed individuals, capable of working, who receive welfare benefits, before the current program/programs started. 
9. Which programs have been in place during the period from 1990 until the start of the current program/programs? Under each heading below, please specify the name of the program, or the main activity if you do not know/there was no name for the program (for example, "Meeting with job counselor"). Please also specify during what years the program/activity was in place.

\section{Program 1:}

Name:

Time period:

Program 2:

Name:

Time period:

[..etc..]

Below follows a set of questions about the programs/activities that were in place before the current program(s). Please answer the questions about each program under the heading that corresponds to the list above.

Program/Activity 1:

1. Which groups were targeted by the program/activity?

2. How large a share of all individuals, capable of working and receiving welfare benefits, were encompassed by the program/activity?

3. Please specify to what extent the following activities were used in the program/activity:

a. Job-seeking activities 
b. Job-training activities

c. Other assigned work (for example, within the municipal services)

d. Other activities (please specify which):

7. Was absence/non-attendance systematically reported to the social service officials?

Yes

No

If yes, in what way:

8. Could absence/non-attendance (without acceptable motives) lead to refusal/rejection of the welfare benefit application?

Yes

No

Comments:

Program/Activity 2:

[The same questions were repeated for all programs/activities listed] 


\section{Appendix C: Register data}

The data used in this paper come from three databases (all of them part of the IFAU database): LOUISE, syss and anst.

- LOUISE: A longitudinal database containing information on education, income and employment for the whole population older than 16 in Sweden. It contains data for all years since 1990.

- Syss: Syss is part of RAMS (registered labor market statistics) and contains data on employers, income from employment and employment from 1985 to 2000. For later years, see LOUISE.

- Anst: Anst is part of RAMS (registered labor market statistics) and contains information about when the employee began work and when the employment was terminated.

Table C.1. Definition of variables

\begin{tabular}{|c|c|c|}
\hline Variable & Database and name & Description \\
\hline \multicolumn{3}{|l|}{ Dependent variables } \\
\hline Welfare recipient & LOUISE: socbidp1* & Indicator variable that takes value 1 if socbidp1 $>0$. \\
\hline Welfare benefits & LOUISE: socbidp1 & $\begin{array}{r}\text { The individual's share of the household's welfare } \\
\text { benefits. Includes zeros. }\end{array}$ \\
\hline Employed in November & sys: syss* & $\begin{array}{l}\text { Indicator variable that takes the value } 1 \text { if an individual is } \\
\text { employed for at least } 1 \text { hour in November. }\end{array}$ \\
\hline Employed all year & $\begin{array}{r}\text { anst: mantill and } \\
\text { manfran }\end{array}$ & $\begin{array}{r}\text { The variable takes the value } 1 \text { if an individual has been } \\
\text { employed a full year in a position that has generated } \\
\text { more than } 25 \text { percent of the minimum wage for a worker } \\
\text { within the hotel and restaurant sector. }\end{array}$ \\
\hline Months employed & $\begin{array}{r}\text { anst: mantill and } \\
\text { manfran }\end{array}$ & $\begin{array}{l}\text { The number of months an individual has been employed } \\
\text { during the year in a position that has generated more } \\
\text { than } 25 \text { percent of the minimum wage for a worker within } \\
\text { the hotel and restaurant sector. }\end{array}$ \\
\hline Income from employment & LOUISE: loneink & $\begin{array}{r}\text { The sum of gross earnings from an employer during the } \\
\text { year. }\end{array}$ \\
\hline Disposable income & LOUISE: dispink & $\begin{array}{r}\text { All income from work and social security systems, } \\
\text { transfers minus taxes, study loan payments, etc. For } \\
\text { details, see SCB }(2005, \text { p. } 190) .\end{array}$ \\
\hline \multicolumn{3}{|c|}{ Variables used for heterogeneous effects } \\
\hline $\begin{array}{l}\text { Two parent household with } \\
\text { young children ( }<7 \text { years) }\end{array}$ & $\begin{array}{l}\text { LOUISE: barn0003 and } \\
\text { barn0406, famstf }\end{array}$ & $\begin{array}{l}\text { Indicator variable that takes the value } 1 \text { if a household is } \\
\text { headed by two adults and has children less than } 7 \text { years } \\
\text { in the household. }\end{array}$ \\
\hline $\begin{array}{l}\text { Single-parent household } \\
\text { with young children }\end{array}$ & $\begin{array}{l}\text { LOUISE: barn0003 and } \\
\text { barn0406, famstf }\end{array}$ & $\begin{array}{l}\text { Indicator variable that takes the value } 1 \text { if a household is } \\
\text { headed by one adult and has children less than } 7 \text { years in }\end{array}$ \\
\hline $18-25$ & LOUISE: fodar* & $\begin{array}{l}\text { Indicator variable that takes the value } 1 \text { if an individual is } \\
\text { within the age interval 18-25. }\end{array}$ \\
\hline
\end{tabular}




\begin{tabular}{|c|c|c|}
\hline Variable & Database and name & Description \\
\hline Born in Sweden & sys: fland & Indicator variable for Sweden as country of birth. \\
\hline Born in Nordic country & sys: fland & $\begin{array}{r}\text { Indicator variable for any of the Nordic countries as } \\
\text { country of birth. }\end{array}$ \\
\hline Born in Western country & sys: fland & $\begin{array}{l}\text { Indicator variable for any of the Western countries as } \\
\text { country of birth (Western Europe, U.S. and Canada). }\end{array}$ \\
\hline Born in Eastern Europe & sys: fland & $\begin{array}{r}\text { Indicator variable for any of the Eastern European } \\
\text { countries as country of birth. }\end{array}$ \\
\hline $\begin{array}{l}\text { Born in other country } \\
\text { Other control variables }\end{array}$ & sys: fland & Indicator variable for any other country of birth. \\
\hline Woman & LOUISE: kon & $\begin{array}{r}\text { Indicator variable that takes value } 1 \text { if an individual is a } \\
\text { woman. }\end{array}$ \\
\hline $\begin{array}{l}\text { Households with young } \\
\text { children ( }<7 \text { years) }\end{array}$ & $\begin{array}{r}\text { LOUISE: barn0003 and } \\
\text { barn0406 }\end{array}$ & $\begin{array}{r}\text { Indicator variable for the presence of children under } 7 \\
\text { years in the household. }\end{array}$ \\
\hline $26-35$ & LOUISE: fodar* & $\begin{array}{r}\text { Indicator variable that takes the value } 1 \text { if an individual is } \\
\text { within the age interval } 26-35\end{array}$ \\
\hline $36-45$ & LOUISE: fodar* & $\begin{array}{r}\text { Indicator variable that takes the value } 1 \text { if an individual is } \\
\text { within the age interval 36-45 }\end{array}$ \\
\hline $46-64$ & LOUISE: fodar* & $\begin{array}{r}\text { Indicator variable that takes the value } 1 \text { if an individual is } \\
\text { within the age interval } 45-64\end{array}$ \\
\hline Children $=1$ & $\begin{array}{r}\text { LOUISE: barn0003, } \\
\text { barn0406, barn0715, } \\
\text { barn1617* }\end{array}$ & $\begin{array}{r}\text { Indicator variable for the presence of one child under } 18 \\
\text { years in the household. }\end{array}$ \\
\hline Children $>1$ & $\begin{array}{r}\text { LOUISE: barn0003, } \\
\text { barn0406, barn0715, } \\
\text { barn1617* }\end{array}$ & $\begin{array}{l}\text { Indicator variable for the presence of more than one child } \\
\text { under } 18 \text { years in the household. }\end{array}$ \\
\hline $\begin{array}{l}\text { Elementary school< } 9 \\
\text { years }\end{array}$ & LOUISE: hsun* & $\begin{array}{l}\text { Indicator variable that takes the value } 1 \text { if the individual's } \\
\text { highest education is elementary school }<9 \text { years. }\end{array}$ \\
\hline Elementary school 9 years & LOUISE: hsun* & $\begin{array}{r}\text { Indicator variable that takes the value } 1 \text { if the individual's } \\
\text { highest education is elementary school } 9 \text { years }\end{array}$ \\
\hline
\end{tabular}

